\title{
DOŚWIADCZENIA NIECIĄGLOŚCI A REFLEKSYJNE UCZENIE SIE NA PODSTAWIE DYLEMATÓW MORALNYCH. STUDIUM JAKOŚCIOWE W RAMACH BADANIA ETIK-INTERNATIONAL EDYNBURG ${ }^{1}$
}

Streszczenie: W związku z realizacją projektu ETiK, które miało miejsce na Uniwersytecie Humboldtów w Berlinie, opracowano Test Komeptencji Moralno-Etycznej Piętnastolatków (TKM-EP). Jego podstawą jest koncepcja, zgodnie z którą w kompetencji moralno-etycznej da się wyodrębnić trzy podkategorie: podstawową wiedzę etyczną, kompetencję sądzenia moralno-etycznego i zdolność projektowania działań w zakresie moralności. Dzięki przeprowadzonym badaniom empirycznym w każdej z wymienionych podkategorii wyróżniono od trzech do czterach poziomów. Planowane w Edynburgu badanie ETiK-International będzie miało na celu dalszą optymalizację TKM-EP. Dokona się to na dwa sposoby: po pierwsze, przy pomocy szkockiego planu nauczania (Curriculum for Excellence) zostaną zweryfikowane hipotezy zawarte w projekcie ETiK, po drugie zaś, do części empirycznej zostanie dodane studium jakościowe, które umożliwi określenie roli, jaką odgrywa doświadczanie nieciągłości występujące u uczniów podczas przechodzenia z jednego poziom kompetencji moralnej na kolejny. Pojęcie „nieciągłość” odnosi się do tych momentów doświadczania, w których nowa idea, inny punkt widzenia czy nieznany do tej pory przedmiot niejako stają przed uczącym się jako wyzwanie, na które początkowo nie ma on gotowej odpowiedzi i musi podjąć się jej poszukiwania.

$\mathrm{W}$ prezentowanym artykule pierwszy rozdział przedstawia rolę, jaką odgrywa wychowanie etyczno-moralne w Wielkiej Brytanii, ze szczególnym jednak uwzględnieniem kontekstu szkockiego. Rozdział drugi zawiera analizę zbieżności zachodzących między pułapem osiągnięć w zakresie przedmiotu Religious and Moral Education (kształcenie religijne i moralne) wyznaczonego przez szkocki plan nauczania (Curriculum for Excellence) i oczekiwaniami ustalonymi w berlińskim projekcie ETiK dla najwyższych poziomów kompetencji moralno-etycznej w każdym z jej zakresów. W kolejnym rozdziale omówiono

${ }^{1}$ [Tekst został opublikowany w języku niemieckim pt. Diskontinuitätserfahrungen als Zugänge zu einem reflektierenden Umgang mit moralischen Dilemmata. Eine qualitative Studie im Rahmen von ETiK-International-Edinburgh w: Benner, Nikolova 2016, s. 236-253. Pochodzące od tłumacza uzupełnienia i dopowiedzenia umieszczono w nawiasach kwadratowych i opatrzono dopiskiem „dop. D.S.”]. 
autorski projekt studium jakościowego, które ma na celu wykorzystanie przy kreowaniu rozumowania moralno-etycznego uczniów doświadczenia nieciągłości wywołanego przez konfrontację z dylematycznymi sytuacjami moralnymi. W ostatnim rozdziale szczególna uwaga została zwrócona na możliwość wykorzystania wyników badań ilościowych i jakościowych, uzyskanych w badaniu ETiK-International do projektowaniu szkoleń i kursów dokształających dla nauczycieli religii i wychowania moralnego ze szkół podstawowych i średnich.

Słowa kluczowe: doświadczenie nieciągłości, badanie ETiK, dylematy moralne, badanie jakościowe.

W tym artykule zostanie przedstawiony zarys zamierzenia badawczego polegającego na przeprowadzeniu badania ETiK-International w Edynburgu. Międzynarodowe badanie ETiK-International korzysta z osiągnięć projektu ETiK, który został zrealizowany na Uniwersytecie Humboldtów w Berlinie. Jego głównym celem było zoperacjonalizowanie autorskiego modelu kompetencji moralno-etycznej, przygotowanego przez zespół kierowany przez Dietricha Bennera i Roumianę Nikolovą (2016). W wyniku przeprowadzonych badań empirycznych opisano tę kompetencję za pomocą trzech kompetencji cząstkowych: podstawowej wiedzy moralno-etycznej (PWM-E), kompetencji sądzenia moralno-etycznego (KSM-E) i kompetencji projektowania działania moralno-etycznego (KPDM-E). W każdej z kompetencji cząstkowych badacze wyodrębnili dodatkowo trzy respective cztery poziomy, które odzwierciedlają oczekiwania stawiane przed osobami osiągającym dany poziom.

Przystępując do adaptacji koncepcji teoretyczno-empirycznej zastosowanej w projekcie ETiK i opracowanego w nim narzędzia badawczego - Testu Kompetencji Moralno-Etycznej Piętnastolatków (TKM-EP), trzeba oczywiście uwzględnić obowiązujące w Szkocji programy kształcenia w zakresie edukacji moralnej. Ponadto do problemów badawczych chciałabym dołączyć pytanie, które interesuje mnie szczególnie z racji moich dotychczasowych poszukiwań naukowych, mianowicie, chciałabym się dowiedzieć, jakie znaczenie dla osobistej biografii kształcenia mają nieciągłości, których doświadczają uczniowie w przejściach między wskazanymi powyżej poziomami oczekiwań moralno-etycznych.

Niniejsze rozważania podzieliłam na trzy części. Najpierw przedstawię uwarunkowania programowe dotyczące wychowania i nauczania moralnego w Wielkiej Brytanii, zwracając uwagę na szczególny status Szkocji. W drugiej części tego artykułu zostaną porównane poziomy oczekiwań uzyskane dzięki ewaluacji berlińskiego projektu ETiK z tymi, które przewiduje się w szkockich dokumentach oświatowych. Trzecia część przybliża koncepcję studium jakościowego, które zamierzam przeprowadzić w Edynburgu w ramach badania ETiK-International jako jego dopełnienie. W tym studium zasadniczy akcent pada na wspomniane powyżej doświadczenia nieciągłości w przechodzeniu między poziomami oczekiwań etyczno-moralnych. Pytanie, które mi przyświeca w tym zakresie, brzmi: Czy da się wykorzystać doświadczenia nieciągłości do tego, żeby pobudzić uczących 
się do refleksyjnego obchodzenia się z dylematami moralnymi, które znajdują się zazwyczaj w centrum edukacji moralnej?

\section{Edukacja moralno-etyczna w Wielkiej Brytanii i Szkocji}

Mimo że w Wielkiej Brytanii powszechnie akceptuje się doniosłe znaczenie szkoły dla rozwoju moralnego i etycznego dorastających, to jednak Szkocja jest jedynym krajem należącym do Zjednoczonego Królestwa, który w swoim Curriculum for Excellence (CfE) wyraźnie wymienia "duchowe, moralne, społeczne i kulturowe” cele edukacji szkolnej (Peterson i in. 2014, s. 11) ${ }^{2}$. W przeciwieństwie do tego w preambule do angielskiego narodowego programu kształcenia z 2014 roku wymienia się właśnie wspomniane rodzaje edukacji - duchową, moralną, społeczna i kulturową - jako ogólne składowe i charakteryzuje je jako balanced and broadly based (Department for Education 2014) ${ }^{3}$. Inspektorzy Ofsted ${ }^{4}$ kontrolują, czy nauczyciele przestrzegają equality of opportunity and recognition of diversity (Ofsted 2015, s. 36), czy umożliwiają na swoich zajęciach nabywanie przez uczniów kompetencji moralnych i społecznych i czy pomagają im rozwijać następujące zdolności: the ability to be reflective about their own beliefs (Ofsted 2015, s. 36) oraz the ability to understand and appreciate the viewpoints of others on [moral and ethical - dop. A.E.] issues (Ofsted 2015, s. 36).

$\mathrm{W}$ ostatnim czasie $\mathrm{w}$ angielskich kręgach akademickich intensywnie podejmowana jest kwestia, na ile rzeczywiście wciela się w życie edukację moralną w szkołach, a na ile jest to tylko postulat. Przegląd stanu wychowania moralnego i nauczania etyczno-moralnego w Wielkiej Brytanii zawierają dwa opracowania, które jednocześnie informują o wyjątkowym statusie, jaki w tym zakresie przysługuje Szkocji. To właśnie predestynuje ją jako miejsce do przeprowadzenia badania ETiK-International.

Pierwsze ze wspomnianych powyżej dwóch opracowań powstało dzięki wsparciu Royal Society of the Arts. Jego autorzy postawili sobie za cel znalezienia odpowiedzi na pytanie o to, czy i w jakim zakresie brytyjskie szkoły wspierają u swoich uczniów spiritual, moral, social and cultural education ${ }^{5}$ (Peterson i in. 2014). W związku z tym najpierw przestudiowali historię SMSC-Education i jej

${ }^{2}$ O historii szkockiego Curriculum for Excellence zob. Priestly 2013 i OECD 2015. Odnośnie do spiritual, moral, social and cultural education zob. Watson 2012.

${ }^{3}$ [Tak jak w wersji niemieckiej fragmentów w języku angielskim nie tłumaczono - dop. D.S.].

${ }^{4}$ Ofsted jest skrótem od Office for Standards in Education, Children's Services and Skills. Instytucja ta powstała w Wielkiej Brytanii w $1992 \mathrm{w}$ celu kontrolowania szeroko rozumianej pracy młodzieżowej, $\mathrm{w}$ tym również incjatyw podejmowanych w tym zakresie przez placówki oświatowe. Ofsted przeprowadza swoje kontrole z polecenia Department for Education (DfE), który jest w pewnym sensie ministerstwem edukacji składającym co roku raport angielskiemu parlamentowi.

${ }^{5}$ Dalej będę używać skrótu SMSC-Education. 
umiejscowienie w prawodawstwie szkolnym Wielkiej Brytanii, a następnie raporty Ofsted i przeprowadzili badania terenowe, w tym wywiady z nauczycielami i uczniami w Anglii, Irlandii Północnej, Szkocji i Walii (Peterson i in. 2014, s. 13 i n.). Okazało się, że istnieją duże dysproporcje odnośnie do kwalifikacji nauczycieli prowadzących zajęcia z SMSC-Education i nastawienia szkół do tych zajęć. Nauczyciele wskazywali, że nie mają na lekcjach wystarczająco wiele czasu, żeby właściwie potraktować tematy z zakresu SMSC-Education. Szczególnie rażące braki pod tym względem wykazuje Anglia, gdzie notabene regularnie poddaje się uczniów różnego rodzaju badaniom za pomocą testów (Peterson i in. 2014, s. 16 i n.). Poza tym nauczyciele sygnalizowali, że unikają kontrowersyjnych tematów moralnych i etycznych ze względu na możliwe protesty ze strony rodziców. W omawianym studium stwierdza się jednak, że uczniowie wykazują wyraźną potrzebę otwartej rozmowy ze swoimi nauczycielami o problemach etycznych, na które napotykają w życiu (Peterson i in. 2014, s. 18) . $^{6}$

W omawianym opracowaniu ustalono, że dyrekcje szkół napotykają na poważne trudności w zakresie kontrolowania pedagogicznego i merytorycznego poziomu lekcji SMSC-Education (Peterson i in. 2014, s. 18). Mimo że inspektorzy Ofsted kładą duży nacisk na ewaluację zajęć szkolnych z MSC-Education, Amelia Peterson i jej współpracownicy dowiedli, że oceny te przeprowadza się według niejednolitych, a niekiedy nawet skrajnie rozbieżnych kryteriów (Peterson i in. 2014, s. 13).

Podsumowując, można stwierdzić, że w studium Schools with Soul pokazano dostatecznie wyraźnie, jak naucza się SMSC-Education w Wielkiej Brytanii. Jego autorzy biją na alarm, twierdząc, że zajęciom tym grozi całkowita marginalizacja (Peterson i in. 2014, s. 16).

Drugie z zapowiadanych powyżej opracowań jest raportem z projektu na temat Religious Education (RE) w Wielkiej Brytanii. Określenie RE odnosi się równocześnie do oddzielnego przedmiotu szkolnego, jak to ma przykładowo miejsce w Anglii i Szkocji ${ }^{7}$ a także konstelacji różnych zajęć szkolnych, w których występują treści religijne. Tym razem wykonanie badania zostało zlecone i sfinansowane przez dwie instytucje: The Economic and Social Research Council i The Arts and Humanities Research Council. Przeprowadził je zespół badawczy pod kierunkiem James C. Conroy'a w roku 2013.

W projekcie zastosowano różnorodne metody, m.in. badanie etnograficzne, które odbyło się w 24 brytyjskich szkołach drugiego stopnia (secondary schools). Miało ono na celu zweryfikowanie, jakie miejsce zajmuje w edukacji szkolnej RE i jakie znaczenie przypisują mu różne grupy interesów (Conroy i in. 2013). W efekcie

${ }^{6}$ W innych opracowaniach zwraca się uwagę, że nauczyciele angielscy obawiają się posądzenia ich o rasizm, jeżeli będą podejmować na lekcjach kontrowersyjne tematy religijne (Miller, Mckenna 2012; Eaude 2012, s. 121).

7 W Szkocji termin Religious Education oznacza zajęcia prowadzone w szkołach konfesyjnych, natomiast w niekonfesyjnych odpowiednikiem tego przedmiotu jest Religious and Moral Education. 
badania wykazano, że RE we wszystkich krajach Wielkiej Brytanii, tj. w Anglii, Irlandii Północnej, Szkocji i Walii, tworzy wyodrębniony obszar w programach nauczania i wiąże się w nierozdzielny sposób z pewnymi „imperatywami moralnymi”, które krzewią religijnie określone postawy moralne (Conroy i in. 2013, s. 42 i n.). Jednocześnie jednak obserwacje i rozmowy z nauczycielami tego „przedmiotu” ujawniły szereg ambiwalencji w ich samorozumieniu. Nierzadko bowiem dyrektorzy szkół powierzają im prowadzenie zajęć o dużej rozpiętości: od making us better human beings, czyli moral development, przez sex education, aż do development of specific „virtues”, multicultural awareness i spiritual and social cohesion (Conroy i in. 2013, s. 43 i n.). Poza tym w wielu szkołach od nauczycieli RE oczekuje się, że będą pełnić rolę „stróżów moralności” i przezwyciężą skłonności do rasizmu u uczniów, napiętnują zachowania antyislamskie i nauczą uczniów obchodzenia się z ksenofobią (Conroy i in. 2013, s. 44). Poza tym, zdaniem nauczycieli RE, $\mathrm{w}$ porównaniu $\mathrm{z}$ nauczycielami innych przedmiotów, np. uczącymi matematyki czy języków obcych, okazuje się im znacznie mniej uznania i szacunku. Nie czują się dowartościowani, co w pewnym stopniu tłumaczy, dlaczego okazują dystans, a nawet obojętność wobec przedmiotu, którego nauczają (Conroy i in. 2013, s. 45; McKinney 2012, s. 43; Nixon 2008, s. 558 i n.).

Wyniki obu badań potwierdzają, że zgodnie z dokumentami oświatowymi MSC-Education jest w Wielkiej Brytanii wyodrębnionym zakresem wychowania i nauczania szkolnego, co pozytywnie świadczy o trosce o rozwój społeczny, etyczny i moralny młodego pokolenia, który w świetle unormowań prawnych należy do integralnych zadań oświaty publicznej, jednak przy realizacji tych zapisów dyrekcje szkół i nauczyciele napotykają na różnorodne trudności. Co prawda, część tych trudności wynika $\mathrm{z}$ uwarunkowań społecznych, a przede wszystkim ze wzrastającej kompleksowości społeczeństwa brytyjskiego i jego różnorodności, w części jednak źródłem problemu jest sama szkoła. W związku z tym w ostatnim opracowaniu podkreśla się, że w przypadku, gdy RE nie stanowi oddzielnego przedmiotu szkolnego, lecz jest „podzielony” między różnych nauczycieli, powstają niejasności co do zakresu odpowiedzialności i kompetencji nauczycieli. Ta uwaga odnosi się również do inspektorów Ofsted. Z całą pewnością taki stan rzeczy dodatkowo utrudnia implementację i ewaluację nie tylko RE, lecz również MSC-Education.

Patrząc na wychowanie i nauczanie moralno-etyczne jako odrębny obszar edukacji publicznej w Wielkiej Brytanii, współcześnie da się zauważyć odmienne tendencje, które szczególnie silnie kontrastują ze sobą w Anglii i Szkocji. Jak opisał wspomniany powyżej zespół badawczy J. Conroy’a, Michael Gove, odpowiedzialny za edukację sekretarz stanu w rządzie angielskim w latach 2010-2014, zespół ten doprowadził do zniesienia dotacji rządowej dla kierunku nauczanie religii w uczelniach przygotowujących przyszłych nauczycieli (Conroy i in. 2013, s. 101 i n.). Ta decyzja z pewnością była związana z jego osobistym nastawieniem do RE, spowodowała jednak dalszą deprecjację tego przedmiotu czy obszaru tematycznego $\mathrm{w}$ angielskich szkołach drugiego stopnia. 
Inny powód zaniepokojenia i obaw o przyszłość RE w Anglii stanowi fakt, że nauczanie w tym zakresie nie jest zakotwiczone w dokumentach oświatowych obowiązujących w tym regionie Wielkiej Brytanii, a odpowiedzialność za zabezpieczenie środków na jego realizację złożono na barki samorządu lokalnego. W niedalekiej przeszłości taki sposób uregulowania czy raczej deregulacji tych problemów doprowadzi do znacznych dysproporcji między poszczególnymi szkołami odnośnie do liczby godzin lekcyjnych i materiału nauczania. To zaś grozi niebezpieczeństwem złamania zapisów prawnych dotyczących obszaru MSCEducation (Chater, Erricker 2013, s. 23 i n.) ${ }^{8}$.

W przeciwieństwo do Anglii, sytuacja w Szkocji przejawia inne tendencje. Jak przedstawię to w następnej części tego artykułu, zgodnie z zapisami szkockiego Curriculum for Excellence, obszar Religious and Moral Education (RME) ${ }^{9}$ tworzy nie tylko odrębny przedmiot szkolnego nauczania w szkołach stopnia pierwszego (primary school) i drugiego (secondary school), lecz również uczniowie, którzy ukończyli 15 rok życia i uzyskali świadectwo Broad General Education, mogą kontynuować naukę w tym obszarze do 18 roku życia. Jest to o tyle ważne, że wówczas stopień uzyskany z RME jest uwzględniany przy przyjęciu na uniwersytet.

\section{Rola wychowania i nauczania moralnego w szkockim Curriculum for Excellence w perspektywie kompetencji moralno-etycznej projektu ETiK}

W konkluzji niedawno opublikowanej filozoficznej analizy szkockiego Curriculum for Excellence (CfE) Nicki Hedge i Alison MacKenzie prezentują wniosek, że ten narodowy program kształcenia wspiera w uczących się autonomię przez to, że skłania ich do uznania godności drugiego człowieka i respektowania jej (Hedge,

8 W szóstym rozdziale swojej publikacji Mark Chater i Clive Erricker (2013) omawiają funkcjonowanie angielskiej instytucji rządowej określanej skrótem SACRE, który oznacza Standing Advisory Councils on Religious Education. Autorzy zwracają uwagę na całkowitą samowolę urzędników przy podejmowaniu istotnych decyzji personalnych i merytorycznych, a także na niemożność wyegzekwowania od nich informacji o kryteriach stosowanych przy ocenianiu RE. M. Chater i C. Erricker przytaczają również series of anomalies and susceptabilities, które doprowadziły do osłabienia statusu RE w całej Anglii.

9 Jak podano powyżej w przypisie 7, w Szkocji Religious and Moral Education (RME) nie jest nazwą jednego przedmiotu, lecz grupy przedmiotów, których nauczanie prowadzi się wyłącznie w szkołach niekonfesyjnych. Poniżej zostanie wyjaśnione umocowanie prawne RME i jej strona instytucjonalna. W raporcie z badania OECD w 2015 roku podano, że oprócz szkół niekonfesjonalnych prowadzi się nauczanie RME w 370 konfesjonalnych placówkach oświatowych finansowanych ze środkow państwowych, spośród których przeważającą część stanowią szkoły katolickie. Organy prowadzące te szkoły zobowiązały sie do przestrzegania zapisów Curriculum for Excellence i prowadzą zajęcia z grupy przedmiotów RME jako lekcje RE. Ponadto w Szkocji funkcjonuje 100 zarejestrowanych prywatnych szkół o niezależnym statusie, w których pobiera naukę około 30 tys. uczniów i uczennic. Szkoły te nie są zobligowane do prowadzenia nauczania zgodnie ze szkockim Curriculum for Excellence (OECD 2015, s. 36). 
MacKenzie 2016). Podobnego zdania jest Graeme Nixon, który uważa, że wyznaczony w CfE cel RME obejmuje w mniejszym stopniu kształtowanie przekonań i postaw uczniów, a raczej wspiera w nich zdolności do myślenia i komunikowania się z innymi odnośnie do problemów dotyczących religii i moralności oraz rozwija empatię względem osób o innym światopoglądzie (Nixon 2013a, s. 495 i n.).

Powyżej przedstawione ukierunkowanie szkockiego CfE wynika z historii REM i musi być przez pryzmat tej historii interpretowane. $Z$ wypowiedzi zawartych w CfE odnośnie do REM da się odtworzyć rozumienie kompetencji moralno-etycznej, które zadziwiająco współgra z rozumieniem wynikającym z opracowania w ramach berlińskiego projektu EtiK i które wykorzystano przy konstruowaniu pytań do Testu Kompetencji Moralno-Etycznej Piętnastolatków (TKM-EP). Ta zgodność podsunęła mi pomysł wykorzystania narzędzia badawczego ETiK do ewaluacji szkockiego CfE i porównania z jego pomocą poziomów kompetencyjnych osiąganych przez uczniów w Szkocji i Niemczech.

\section{Zarys historii Religious and Moral Education w Szkocji}

W historii RME w Szkocji szczególne znaczenie odegrały dwa dokumenty. Pierwszy z nich to pochodzący z 1872 roku Education Act, w którym zapisane zostało prawo każdego dziecka do kształcenia religijnego. Dokument ten zawiera klauzulę sumienia, zgodnie z którą rodzice mogą zrezygnować z udziału ich dziecka w kształceniu religijnym (Nixon 2013a, s. 493 i n.).

Drugim znaczącym dokumentem w szkockiej historii RME jest wydany przez Scottish Education Department (SED) dokładnie 100 lat po Education Act, tj. w 1972 roku, raport pt. Moral and Religious education in Scottish Schools, który skrótowo określa się również raportem Millar. Był on próbą uchwycenia u progu lat 7o. minionego stulecia status quo RME w Szkocji i wskazania sposobu jej dalszego nauczania. Na podstawie tego właśnie raportu nadano RME kierunek mniej nomatywny i preskrypcyjny (McKinney 2012).

Naukowcy zajmujący się omawianą problematyką przypisują raportowi Millar decydującą rolę w powstaniu szkockiej wersji RME, której specyfika polega na tym, że obszar ten traktowany jest w Szkocji nie jako peryferia, lecz jako serce edukacji szkolnej. W związku z tym od 1993 roku nadzór nad RME został powierzony bezpośrednio Her Majesty's Inspectorate (McKinney 2012). Poza tym, jak podkreśla G. Nixon, raport Millar spowodował wzmocnienie filozoficznego ukierunkowania zajęć z RME, dzięki czemu wzrosło znaczenie pluralistycznych form myślenia, nowoczesnych metod nauczania i kompetencji uczniów (Nixon 2013b, s. 640 i n.). W obowiązującej obecnie koncepcji RME skrupulatnie odseparowuje się moralność od treści związanych z ponadnaturalnymi religiami teistycznymi. Przez to etyka i moralność jako zakres tematyczny RME zyskały nie tylko na samodzielności, lecz również na znaczeniu. Nauczyciele przygotowujący się do nauczania tego przedmiotu muszą posiąść profesjonalną wiedzę z tego zakresu (Nixon 2013b, s. 641). 
Zdaniem G. Nixona, raport Millar był w polityce oświatowej źródłem impulsów, które doprowadziły do wykrystalizowania się kolejnego obszaru działalności oświaty publicznej, a mianowicie Personal Search. Tym mianem określa się działania edukacyjne mające na celu udzielenie uczniom wsparcia w procesie poszukiwania własnej tożsamości i samookreśleniu. Należy do tego dodać również formowanie indywidualnych przekonań i własnego światopoglądu. W wydanym w 2006 roku dokumencie Scottish Executive uznano aktywność instytucji oświatowych w tym obszarze za istotny wkład w urzeczywistnienie zapisów CfE i za główny cel zajęć z RME (Scottish Executive 2006, s. 25). Realizacja tego celu wymaga od nauczycieli posiadania nie tylko wiedzy z zakresu etyki, lecz także kompetencji pedagogicznych, a w szczególności wychowania do wartości i rozwijania w uczących się kompetencji sądzenia moralno-etycznego (Hartshorn 2008, s. 376).

\section{Pozycja wychowania i nauczania moralno-etycznego w szkockim Curriculum for Excellence}

Według Franka Lennona wiodącą ideą raportu Millar było złożenie na barkach szkoły odpowiedzialności nie tylko za przekaz wiedzy, lecz również za pomoc uczniom w rozwoju osobowym (Lennon 2008, s. 384). To zadanie zostało uznane za główny punkt odniesienia przy opracowywaniu nowego szkockiego programu nauczania - CfE. W programie tym RME zdobyła samodzielność jako autonomiczny obszar edukacji szkolnej, który opisano za pomocą Four Capacities i postawiono ponad zakresem Health and Wellbeing Across Learning.

Zaanonsowane powyżej Four Capacities w syntetyczny sposób streszczają cele nowego CfE (Education Scotland-PoC). Wszystkim uczniom obiecuje się w nim osiągnięcie co najmniej czterech umiejętności: 1) Successful Learners; 2) Confident Individuals; 3) Effective Contributors i w końcu 4) Responsible Citizens. Każda $\mathrm{z}$ tych umiejętności składa się $\mathrm{z}$ odpowiednich attributes i capabilities (Education Scotland-PoC; Hedge, Mackenzie 2016). Poniżej zostaną szczegółowo opisane attributes i capabilities należące do wymienionej na czwartym miejscu umiejętności Responsible Citizens. Tworzą one sedno kompetencji moralno-etycznej, do osiągnięcia której ma prowadzić realizacja nowego CfE, a jednocześnie, moim zdaniem, wykazują dużą zbieżność z modelem kompetencji opracowanym w projekcie ETiK i stanowiącym również podstawę badania ETiK-International.

Mianem Responsible Citizens określa się w zmodyfikowanym CfE ludzi, których odnośnie do attributes i capabilities cechuje odpowiednio: 1) respect for others and commitment to participate responsibly in political, economic, social and cultural life oraz 2) knowledge and understanding of the world and Scotland's place in it; understanding different beliefs and cultures; making informed choices and decisions; evaluating environmental, scientific and technological issues; and developing informed, ethical views of complex issues (Education Scotland-PoC). Nicki Hedge i Alison MacKenzie intepretują te zapisy jako enumerację pożądanych właściwości 
osoby, która będzie odpowiedzialnie angażować się w życie obywatelskie. Żeby to osiągnąć, należy z pomocą edukacji szkolnej wspierać w uczących się rozwój indywidualnej i relacyjnej autonomii. Dzięki tej ostatniej będą oni w stanie postrzegać siebie samych jako embodied and interdependent persons (Hedge, MacKenzie 2016, s. 7). W tym sensie autonomia relacjonalna jest committed to the rights, welfare, dignity, freedom and equality of persons, and recognises vulnerability and dependency (Hedge, MacKenzie 2016, s. 9) i krańcowo sprzeciwia się indywidualizmowi rozumianemu neoliberalnie (Hedge, MacKenzie 2016, s. 9 i n.).

Idea Responsible Citizens, jak ją się prezentuje w CfE, implikuje posiadanie innych jeszcze specyficznych właściwości o charakterze relacyjnym. Należy do nich m.in. umiejętność prowadzenia racjonalnego namysłu nad złożonymi zagadnieniami etycznymi. To z kolei wymaga od uczniów umiejętności collective (classroom) deliberation about what makes an issue ethical and what kinds of actions should follow (Hedge, Mackenzie 2016, s. 7). Czy i na ile taki rodzaj debaty etycznej może wchodzić w zakres programu nauczania RME, zostanie omówione nieco później.

Oprócz szczegółowej charakterystyki Four Capacities w CfE wzięto pod uwagę jeszcze trzy obszary interdyscyplinarnego nauczania i uczenia się, a mianowicie: 1) Health and Wellbeing; 2) Literacy i 3) Numeracy. W obszarach tych wymienia się zróżnicowane treści, których układ i realizacja pozostawiono w gestii nauczycieli.

Paradoksalnie w obszarze opatrzonym mianem Health and Wellbeing nie chodzi w pierwszym rzędzie o zdrowie cielesne. Zapisy CfE skłaniają raczej do wniosku, że ich przedmiotem jest zdrowie rozumiane holistycznie, tzn. z uwzględnieniem aspektów mentalnego, emocjonalnego, społecznego i psychicznego. We wskazaniach programowych dotyczących Health and Wellbeing zwraca uwagę akcentowanie celów nauczania z zakresu wychowania moralnego i etyki. Przykładowo wylicza się tam: rozwój poczucia własnej wartości, poszanowanie innych, umiejętność nawiązywania i pielęgnowania relacji międzyludzkich, uznanie dla różnorodności i gotowość przyjęcia odpowiedzialności za dobro wspólne, krytyczne nastawienie do przejawów dyskryminacji i ich eliminowanie z własnego życia (Education Scotland-HWL). Poza tym omawiane wskazania nakładają na nauczycieli obowiązek przygotowania środowiska uczenia się tak, żeby: Adults have responsibility to look after them and listen to [their] concerns (Education Scotland-HWL). To oznacza, że realizacja treści programowych z obszaru Health and Wellbeing ma zmieniać również etos szkolny, przekształcając go w kierunku międzygeneracyjnego dzielenia trosk i odpowiedzialności oraz obopólnego wspierania się dorosłych i dorastających. W tym układzie uczniowie nie są redukowani do tych, którzy są pouczani, lecz mają przyjąć na siebie odpowiedzialność za własne uczenie się. Ta zmiana dotyczy również, a może przede wszystkim, sfery moralno-etycznej. Podjęcie odpowiedzialności w tym zakresie zakłada zrozumienie swoich etycznych obowiązków i dobrowolne podporządkowanie się im.

W niekonfesjonalnych szkołach w Szkocji RME składa się w sumie z ośmiu prawnie przepisanych przedmiotów obowiązkowych. Uczniowie zamierzający 
podjąć studia wyższe mogą, po wstępnej fazie o charakterze ogólnym, wybrać dodatkowo kurs o nazwie Religious, Moral and Philosophical Studies, który dostarcza im punktów koniecznych do przyjęcia na uniwersytet.

Jak wszystkie przedmioty obowiązkowe, RME jest podzielona na dwa stopnie: Experiences and Outcomes (E’s and O’s), które różnią się poziomem trudności. W odniesieniu do chrześcijaństwa i pozostałych wielkich religii świata złożoność treści i poziomy oczekiwań są dość wysokie. Oprócz wiedzy uczniowie powinni bowiem rozwinąć w sobie właściwe postawy dotyczące norm i wartości, które zwracają przede wszystkim uwagę na okazywanie respect for others and understanding of [others] beliefs and values (Education Scotland-RMEEO, s. 8). W odróżnieniu od innych zakresów nauczania szkolnego zadaniem RME jest ukształtowanie $\mathrm{w}$ uczniach skills of reflection, discernment, critical thinking and deciding how to act when making moral decisions (Scottish Executive, 2006). W związku z tym dużą wagę przypisuje się rozwijaniu zdolności reflektowania i krytycznego myślenia, co przewija się na obu wspomnianych powyżej stopniach RME - Experiences and Outcomes $^{10}$.

Dobrą ilustracją tego, na jakie formy wsparcia mogą liczyć nauczyciele RME przy tak wysoko postawionych wymaganiach, jest następujący przykład. Odnosi się on do czwartego poziomu na obu stopniach - Experiences and Outcomes - w szkole drugiego stopnia, czyli wobec uczniów w wieku 14-16 lat. Ten poziom został przeze mnie wybrany dlatego, że koresponduje z grupą wiekową, której będzie dotyczyło badanie ETiK-International. Od ucznia znajdującego się na czwartym poziomie oczekuje się, że: Having reflected upon and considered a range of belief systems and moral viewpoints, I can express reasoned views on how putting these beliefs and values into action might lead to changes in society (Education Scotland-RMEEO). Takie wypowiedzi jak ta określa się Experiences i Outcomes. Są w nich zawarte równocześnie odniesienia do praktyki życiowej, jak i wiedzy, przy czym ta ostatnia nie jest suchą teorią, lecz powstaje dzięki refleksji ucznia nad własnym doświadczeniem. $\mathrm{W}$ przytoczonym przykładzie przedmiotem doświadczenia są różnorodne systemy wierzeń i zajmowane przez nie stanowiska moralne, które należy poddać namysłowi i refleksji. Lekcje szkolne muszą być prowadzone w taki sposób, żeby każdy uczeń miał możliwość wejścia w kontakt z koniecznym doświadczeniem, które warunkuje jego proces uczenia się. Zapośredniczenie doświadczenia może dokonać się przez własne poszukiwania ucznia, przez zorganizowanie w klasie debaty o odmiennych interpretacjach określonych stanów rzeczy, przez zadanie do napisania eseju na temat wyznawanych wartości i ich miejsca w życiu społecznym itp.

10 Więcej szczegółów na temat Experiences and Outcomes w ramach RME zob. Nixon 2013a. 


\section{Związki między osiągnięciami w zakresie RME a kompetencją moralno- -etyczną w projekcie ETiK}

W dokumencie oświatowym Religious and Moral Education: Principles and Practice przyznaje się RME szczególne znaczenie w odniesieniu do budowania i umacniania w uczniach wiedzy moralno-etycznej oraz rozwijania w nich zdolności sądzenie i działania moralnego. Przyrost wiadomości i umiejętności w wymienionych trzech zakresach ma rozciągać się na cztery hierarchicznie uporządkowane poziomy i uzdalniać uczniów do tego, aby ze zrozumieniem podchodzili do postaw religijnych i niereligijnych; zastanawiali się nad challenges posed by these beliefs and values (Education Scotland-RMEPP, s. 1); refleksyjnie prześwietlali własne przekonania i sądy moralne; przyjmowali responsible attitudes to other people values (Education Scotland-RMEPP, s. 1) oraz rozwijali w sobie zdolność to assist in counteracting prejudice and intolerance values (Education Scotland-RMEPP, s. 1). Wymienione kryteria, od których zależy efektywność RME, wykazują, moim zdaniem, ogromną zbieżność z poziomami oczekiwań (Anforderungsniveaus) wyodrębnionymi podczas realizacji berlińskiego projektu ETiK. Przedstawienie tego jest głównym celem dalszych rozważań w tej części.

Koncepcja kompetencji moralno-etycznej, którą przyjęto w Berlinie, dzieli się na trzy obszary: 1) podstawowa wiedza moralno-etyczna (PWM-E); 2) kompetencja sądzenia moralno-etycznego (KSM-E) i 3) kompetencja projektowania działania moralno-etycznego (KPDM-E) (Benner, Nikolova 2016, s. 130-173). Na tej podstwie opracowano narzędzie badawcze w postaci TKM-EP, w którym wymienione kompetencje cząstkowe połączono z pięcioma respectie dziesięcioma elementarnymi sądami moralnymi i odniesiono jeszcze do trzech sfer moralności: intrapersonalnej, interpersonalnej i społecznej. Zadania testowe werbalizują ten złożony konstrukt teoretyczny w nawiązaniu do sytuacji zbliżonych do życia codziennego. W nich bowiem powinny się sprawdzać wiedza i umiejętności zdobywane w szkole.

$\mathrm{W}$ poniższej tabeli zestawiono opisy czwartego, $\mathrm{tj}$. jest najwyższego poziomu kompetencyjnego z trzech źródeł: koncepcji kompetencji moralno-etycznej projektu ETiK (lewa kolumna), zawartego w CfE wykazu ogólnych umiejętności, jakie winni posiąść uczniowie uczęszczający w Szkocji na RME (środkowa kolumna) i wykazu szczegółowych osiągnięć, jakimi powinni się wykazywać uczniowie na czwartym poziomie RME (prawa kolumna) ${ }^{11}$. Należy w tym miejscu nadmienić, że w badaniu ETiK-International w Edynburgu planuje się przeprowadzenie testów wśród uczniów uczęszczających do szkół drugiego poziomu, którzy w zakresie

11 Wypowiedzi cytowane w środkowej kolumnie pochodzą z Education Scotland-RMEEO, te z prawej natomiast zaczerpnięto z Education Scotland (2014b, s. 2-3). Co prawda, w katalogu osiągnięć edukacyjnych RME istnieje jeszcze tzw. Senior Level, który przewyższa analizowany tutaj czwarty poziom, jednak wykracza on poza obowiązkowe kształcenie ogólne i dotyczy nastolatków mających więcej niż 16 lat, ktorzy chcą zdobyć dodatkowe kwalifikacje (Bryce 2013). 
RME osiągają omówiony powyżej czwarty poziom. Jak wyraźnie wynika z tabeli, na poziomie tym nie określono dokładnie, jakie wiadomości i formy sądzenia moralno-etycznego powinni uczniowie sobie przyswoić. $Z$ tego powodu nie ma bezpośrednich wskaźników, które umożliwiją przełożenie poziomów oczekiwań z projektu ETiK na poziomy w RME. Niemniej jednak, na podstawie analizy celów zawartych w szkockich dokumentach oświatowych, da się uzyskać pogłębione rozumienie tych celów i oczekiwań za nimi stojących. Te ostatnie składają się na koncepcję kompetencji moralno-etycznych, które implicite determinują pomiar osiągnięć edukacyjnych w zakresie RME. W opracowanym na bazie CfE dokumencie pt. Religious and Moral Education - Assessing Progress and Achievement przez osiągnięcie edukacyjne (achievement) rozumie się: 1) Appreciate the importance of respect for the beliefs, values and traditions of others and being able to demonstrate this (Education Scotland, 2014b, s. 1) i 2) Engaging in a process of personal reflection leading to an increasing understanding of personal beliefs and ideas about meaning, value and purpose in life (Education Scotland, 2014b, s. 1).

Z przedstawionej powyżej tabeli wynika, że w zapisach szkockiego CfE duży nacisk kładzie się na uzyskanie przez uczniów uczęszczających na zajęcia RME umiejętności przeprowadzania oceny moralnej problemów i podejmowanie racjonalnie uzasadnionych decyzji w tym zakresie. Sformułowania użyte w CfE pozostawiają nauczycielom znaczną swobodę odnośnie do sposobu wypełnienia tych zadań przez uczniów. Być może to właśnie powoduje, że w wielu raportach na temat realizacji celów nauczania w zakresie RME z ostatnich lat, m.in. z 2015 roku, powtarza się zarzut niezadowalającego wspierania uczniów w osiągnięciu poziomu myślenia abstrakcyjnego (Educational Scotland 2014, s. 4). W tym kontekście naukowcy współpracujący z OECD zaproponowali opracowanie narzędzi i procedur umożliwiających ewaluację celów RME zapisanych w CfE (OECD, 2015, s. 12). Postulowane instrumenty pomiarowe nie zostały do tej pory przygotowane. W związku z tym warto odwołać się do berlińskiego projektu ETiK, w trakcie którego wypracowano nie tylko koncepcję kompetencji moralno-etycznych, lecz również narzędzie do ich mierzenia - TKM-EP. Wydaje się, że adaptacja tego narzędzia i zastosowanie go w Szkocji przyniesie zainteresowanym stronom obopólną korzyść.

\section{Znaczenie nieciągłości przy rozpatrywaniu dylematów moralnych przez uczniów. Studium jakościowe}

Autorzy najnowszych opracowań z zakresu filozofii i psychologii uczenia się udowadniają, że doświadczenia zawierające elementy nieciągłości mogą mieć konstytutywny wpływ na kształtowanie moralności (Brüggen 1988; Benner 2003; Oser, Spychinger 2005; Benner 2008; English 2013). Zdaniem innych doświadczenia te wspierają rozwój kompetencji koniecznych do sądzenia moralnego, m.in. zdolności do samorefleksji i myślenia krytycznego (Lipman 2003; Paul 2012). Również w opracowanym na nowo szkockim Curriculum for Excellence (CfE) wyraźnie 
[13] DOŚWIADCZENIA NIECIĄGŁOŚCI A REFLEKSYJNE UCZENIE SIĘ...

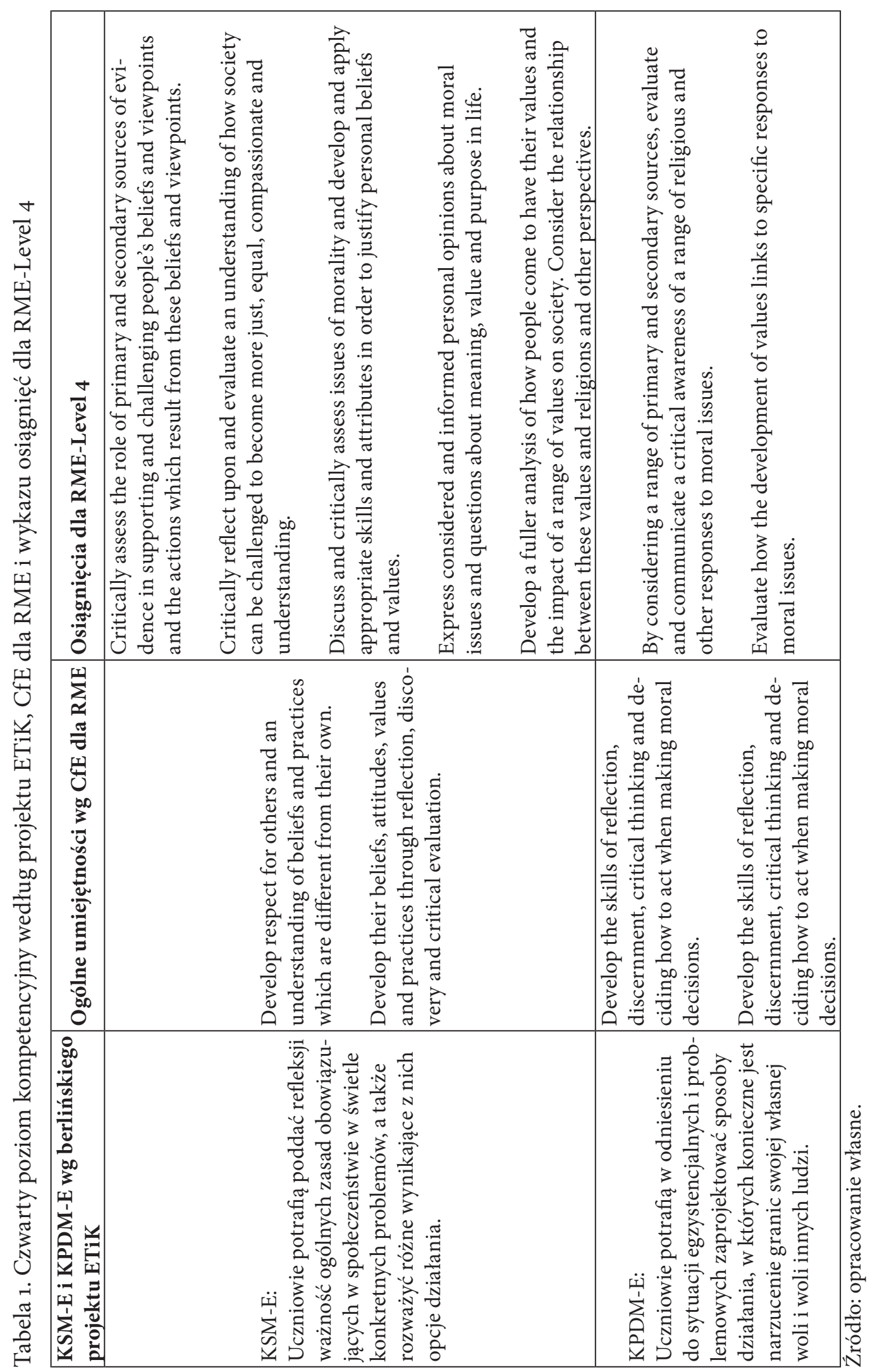


dostrzega się świadome dążenie do angażowania uczących się w proces zdobywania wiedzy. Wyrazem tego jest siedem zasad prowadzania zajęć, które zostały w nim sformułowane (Education Scotland-CfE). W zakresie RME oczekuje się od nauczycieli, że będą m.in. wyzwalać w swoich uczniach moral challenge (Education Scotland-CfE, s. 7). Jednak co dokładnie należy rozumieć przez moral challenge, nie zostało wyjaśnione albo mówiąc pozytywnie - pozostaje sprawą otwartą. Wydaje się, że można to zadanie zinterpretować w ten sposób, że edukatorzy w procesie nauczania moralności mają wzbudzać w uczących się doświadczenia nieciągłości, które skłonią ich do refleksji moralnej.

W ramach studium jakościowego, które planuje się w związku z realizacją badania ETiK-International w Edynburgu, zostanie sprawdzone, na ile szkoccy uczniowie są w stanie sprostać stawianym przed nimi wymaganiom, a w szczególności refleksyjnie i krytycznie rozważać dylematy moralne, za pomocą których wyrażone zostanie zadanie moral challenge. Jeżeli uda się wykazać, że praca nad wykorzystującymi negatywne doświadczenia dylematami moralnymi wspiera w uczniach proces kształcenia moralności, wówczas być może doprecyzuje to również różnice między poszczególnymi poziomami oczekiwań, które wyodrębniono w projekcie ETiK. Takie doprecyzowanie będzie miało również znaczenie dla uzasadnienia berlińskiej koncepcji kompetencji moralno-etycznej i wykorzystanego w tym projekcie zróżnicowania między zadaniami dydaktycznymi a pytaniami testowymi.

Koncypowane dla Edynburga ilościowe i jakościowe badanie ETiK-International zostanie przeprowadzone w grupie 600-800 uczniów i uczennic uczestniczących w zajęciach z RME. Procentowy udział tych, którzy zostaną objęci studium jakościowym, powinien wynieść około 5 proc. $(\mathrm{n}=30-40$ osób). W celu wywołania nieciągłości w zakresie doświadczeń moralnych i spowodowania namysłu nad ukazującymi się w nich problemami moralnymi, zadania poddane analizie jakościowej będą dotyczyć wyłącznie tych dylematów moralnych, które znalazły się w TKM-EP w odniesieniu do jednej tylko kompetencji cząstkowej, a mianowicie KPDM-E. Doświadczenia nieciągłości wyróżnia to, że w zgromadzonym do tej pory rezerwuarze doświadczeń tworzą one swoiste „ślepe plamy”, które mogą zostać uświadomione przez uczącego się wówczas, gdy zderzy się on z granicami własnej wiedzy i umiejętności. Te granice manifestują, że pewne założenia i schematy działania, które do pory sprawdzały się i wystarczały, w obliczu nowych sytuacji problemowych przestają wystarczać i wymagają rewizji. Dylematy moralne znakomicie nadają się do wywołania opisywanych doświadczeń „ślepych plam” dlatego, że nie rozstrzygają na początku ani nie sugerują z góry właściwego rozwiązania. Sytuacja, która może rozpocząć uczenie się z dylematu moralnego, odznacza się tym, że dostarcza możliwości eksperymentalnego przepracowywania problemu przez naświetlanie go z różnych perspektyw i poszukiwanie w otwartej przestrzeni hipotetycznych rozwiązań najodpowiedniejszych do danych warunków.

W studium jakościowym należy wyjaśnić, czy refleksyjne i krytyczne procesy myślenia są w stanie pokazać odniesienia do osobistych negatywnych doświadczeń 
i nieciągłości, które ujawnią się przez hipotetyczne rozumowania nad problemowymi sytuacjami moralnymi. Tych odniesień nie da się jednak zlokalizować bezpośrednio w odpowiedziach respondentów na pytania-zadania TKM-EP. Dlatego w badaniu ETiK-International w Edynburgu zostanie wykorzystana dodatkowa metoda badawcza - sondaż diagnostyczny. Za pomocą wywiadów z uczniami i uczennicami podjęta zostanie próba zwerbalizowania procesów refleksyjnych, które przebiegają implicite $\mathrm{w}$ trakcie rozwiązywania zadań testowych w odniesieniu do wybranego, najwyższego poziomu cząstkowej kompetencji moralno-etycznej KPDM-E. Jako naukowiec dzięki temu badaniu spodziewam się pozyskać głębsze zrozumienie dla schematów myślowych, które tworzą uczniowie znajdujący się w sytuacji przemyśliwania kwestii moralnych. Być może da się również wykorzystać tę wiedzę w takim planowaniu kształcenia moralności, które pozwoli uczniom osiągnąć najwyższy poziom kompetencji moralno-etycznej.

Poniżej zostanie doprecyzowany kontekst teoretyczny projektowanego badania jakościowego. Następnie zostanie wyjaśnione, w jaki sposób dane jakościowe mogą uzupełnić wyniki uzyskane za pomocą instrumentów badawczych ilościowych, a w szczególności za pomocą TKM-EP. W końcu zastanowię się nad pytaniem, jak rezultaty obu części badania ETiK-International w Edynburgu można spożytkować w programach kształcenia i dokształcania nauczycieli.

\section{Teoretyczne przesłanki studium jakościowego}

Współcześnie filozofowie kształcenia zmagają się nieustannie z klasyczną kwestią rolą odgrywaną przez nieciągłość w procesie nauczania i uczenia się. Wyjaśnienie tego, o jaką nieciągłość mi chodzi, chciałabym oprzeć przede wszystkim o dzieła Johanna F. Herbarta i Johna Dewey’a (English 2013) oraz opracowania nieco bardziej współczesne, w których moim zdaniem pogłębiono rozumienie intencji obu wymienionych najpierw autorów i zwrócono szczególną uwagę na znaczenie w uczeniu się takich przeżyć, jak wątpliwości, niezadowolenie, dezorientacja czy wyobcowanie (Passmore 1967; Oser 1998; Burbules 2000; Benner 2003; Kerdeman 2003; Oser 2005; Meyer-Drawe 2008). Negatywne doświadczenia, obdarzone potencjałem kształcącym, nie są „Zwyczajnymi” negatywnymi doświadczeniami, takimi jak: porażka, niepowodzenie, pomyłka itp., lecz powstają w rezultacie refleksyjnego zmagania się z wymienionymi powyżej przeżyciami. Ich kształcąca siła pochodzi z dwóch źródeł równocześnie - po pierwsze, z dostrzeżenia różnicy, której symptomem jest poczucie obcości i inności, i po drugie, z otwarcia na „spotkanie” z nimi. To właśnie stanowi fundament uczenia się przez konfrontację z nieznanym i nowym.

W filozofii zaproponowano szereg dróg, które opisany powyżej rodzaj doświadczenia analizują i rozważają. Platon w kontekście życia społeczno-politycznego opisał w micie o jaskini kształcenie jako zmianę kierunku patrzenia, która w nauczaniu implikuje potrzebę posiadania „sztuki”, zwracania oczu w inną stronę. Oczywiście, chodzi o oczy duszy i duchową zmianę kierunku patrzenia (Platon 
1990, s. 365). Podobnie pisze wspomniany powyżej Herbart, którego zdaniem decyzję moralno-etyczną poprzedza specyficzna walka - „walka z samym sobą” (Herbart 2007, s. 132). Wychowanek wchodzi w taką walkę, gdy interakcje z innymi ujawniają istnienie w nim samym „ślepych plam”, które zmuszają go do tego, żeby podczas podejmowania decyzji wziął pod uwagę potrzeby i interesy innych osób, mimo że sprzeciwiają się one jego własnym interesom. Rozwiązanie takich sytuacji wcale nie jest podane jak na dłoni i musi zostać najpierw znalezione. W tym kontekście Dewey podkreśla kształcącą rolę różnych form doświadczenia nieciągłości, włącznie z takimi, jak: wątpliwość, trudność czy frustracja (Dewey 1963, s. 162 i n.; English 2006). Jego zdaniem doświadczenia tego rodzaju przymuszają uczącego się do skonfrontowania się z nowym wyobrażeniami i stanami rzeczy. Nieciągłość jest w nich niejako konstytutywnym elementem, który warto i należy wykorzystać w procesie uczenia, w tym również uczenia (się) moralności (Benner, English 2004; English 2013).

We wskazanym pod koniec poprzedniego akapitu uczeniu (się) moralności doświadczenia nieciągłości mogą wystąpić przykładowo $\mathrm{w}$ postaci polemiki z innymi przekonaniami religijnymi, politycznymi czy moralnymi, które z kolei warunkowane są różnicami kulturowymi i cywilizacyjnymi. Według Dewey’a takie polemiki mogą wywoływać reflective thinking (Dewey 1963, s. 156), co tworzy niejako pomost prowadzący do zrozumienia cudzych wyobrażeń i poglądów (English 2013, s. 55 i n.). Materiał do refleksyjnego uczenia się przez doświadczenie można znaleźć właściwie wszędzie, a zwłaszcza tam, gdzie napierają na siebie odmienne kultury czy punkty widzenia. W tych warunkach hipotetyczne dylematy moralne dostarczają fikcyjnych sytuacji problemowych, które mogą zostać wykorzystane w procesie uczenia się. Ich zastanawiający charakter skłania uczniów do namysłu nie tylko nad problemem nakreślonym przez fabułę, lecz również, a może przede wszystkim, nad własnymi przekonaniami, czymś, co wydaje się pewne i nad wydawaniem sądów.

Niewątpliwie Dewey'owskie reflective thinking jest spokrewnione z myśleniem krytycznym (Lipman 2003). W obu decydującą rolę odgrywa wątpliwość i niepewność, które nie tylko wskazują na nieciągłość doświadczenia, ale właśnie z niej wynikają. Myślenie refleksyjne cechuje się tym, że werbalizuje doznane przerwy i nieciągłości, czyniąc je przedmiotem produktywnego przemyśliwania sytuacji problemowej i poszukiwania możliwych dróg wyjścia z niej. Takie twórcze i konstruktywne obchodzenie się z własnymi doświadczeniami wymaga nie tylko odpowiednich umiejętności kognitywnych, lecz również psychicznych. Wywołane wątpliwościami poszukiwanie odpowiedzi wcale nie jest łatwym do zniesienia stanem wewnętrznym osoby uczącej się. Sporo racji miał Herbart, nazywając stan ten walką, która na pewnym poziomie nieodłącznie towarzyszy uczącemu się. Odnosząc to do rozważanego kontekstu uczenia (się) moralności, można powiedzieć, że walkę wewnętrzną sygnalizuje już samo pojawienie się odmiennych od własnego punktów widzenia i związana z tym konieczność zmierzenia się z nimi. 
Zdaniem Dewey’a jest to nieunikniony stan struggle, w którym uczący się doświadcza granic zarówno swojej wiedzy, jak i doświadczenia, i rozpoczyna wspomnianą powyżej polemikę. W ten sposób powstaje w nim swoistego rodzaju przestrzeń uczenia się - in-between realm oflearning. Ta przestrzeń rozpościera się między tym, co już znane i „wyuczone”, a tym, co nieznane i nowe. Aby efektywnie wykorzystać doświadczenia pojawiające się w tej przestrzeni, trzeba właściwie pokierować procesami myślenia i uczenia się. Według Käte Meyer-Drawe od nauczyciela operującego w tej przestrzeni wymaga się umiejętności sprzęgania ze sobą przeszłych doświadczeń uczenia się z nowymi doświadczeniami (Meyer-Drawe 2008).

Aby wyjść zwycięsko ze wskazanej powyżej walki wewnętrznej i jednocześnie bez obaw podjąć wyzwanie polegające na „eksperymentowaniu” z własnymi ideami i przekonaniami, uczący musi dysponować, po pierwsze, wystarczającą wyobraźnią, która umożliwi mu wczucie się w stany rzeczy wykraczające poza jego dotychczasowy krąg doświadczenia, i po drugie, gotowością do emptatycznego zrozumienia innego (Fesmire 2003; Dewey 2014; English 2016). Zapośredniczona przez negatywne doświadczenia walka przebiega produktywnie wtedy, gdy nie tylko prowadzi do postawienia pod znakiem zapytania niekwestionowanych dotychczas oczywistości, lecz również otwiera drogę do samorefleksji. Przedmiotem tej samorefleksji jest i to, co już znane, i to, co nowe; i to, co uczący się już potrafil, i to, czego się już nauczył. Na tej podstawie można postawić hipotezę, że konfrontacja z tym, co inne, jest istotnym elementem naszego doświadzenia i w tym doświadczeniu już się zawiera implicite jako jego negatywność. Interpretacja polegająca na oddzieleniu tego, co własne, od tego, co cudze, nie oznacza niczego innego, jak uczenie się i głęboko zakotwiczony w istotę człowieka jego specyficznie ludzki sposób bycia.

\section{Charakterystyka jakościowego zamierzenia badawczego}

Opracowany przez zespół badawczy projektu ETiK Test Kompetencji Moralno-Etycznej Piętnastolatków (TKM-EP) w części odnoszącej się do kompetencji cząstkowej, nazwanej kompetencją planowania działania moralno-etycznego (KPDM-E), przedkłada respondentom do rozważenia fikcyjne sytuacje problemowe, które mają znamiona dylematów moralnych. Zadaniem uczniów jest wybranie odpowiedzi przez zakreślenie jednego rozwiązania lub więcej rozwiązań spośród zaproponowanych i niejako skonstruowanie w ten sposób rozwiązania problematycznej sytuacji. W trakcie konstruowania respective wybierania testowane osoby mniej lub bardziej świadomie koncypują plan działania uwzględniający różne aspekty sytuacji i problemu. W odróżnieniu od słynnych badań przeprowadzonych przez Lawrence’a Kohlberga, w TKM-EP nie wyklucza się z góry możliwości istnienia trzeciej drogi jako rozwiązania dylematu moralnego, co więcej tę opcję niemieccy badacze expressis verbis rekomendują respondentom w tekście wprowadzającym do badania. Pytania dotyczące KPDM-E sformułowano tak, żeby dylematy moralne, które werbalizują, nie tworzyły przestrzeni zamkniętej, lecz właśnie otwartą na 
refleksję i poszukiwanie rozwiązań przestrzeń dzięki zastosowaniu myślenia eksperymentalnego (Benner, Nikolova 2016, s. 13-44). W związku z tym respondenci otrzymują nie tylko informacje na temat problemu, lecz również wskazówki odnośnie do aspektu, pod którym należy go przemyśleć. Jako przykład można podać następujące zadanie dotyczące najwyższego, tj. czwartego poziomu oczekiwań w zakresie KPDM-E.

Tabela 2. Przykład pytania testowego z TKM-EP

Wyobraź sobie, że znalazłeś/aś się w sytuacji, w której pedagog szkolny pyta Cię o to, czy Twoja przyjaciółka zażywa narkotyki. $Z$ bezpośrednich rozmów z nią wiesz, że tak jest. Nawet martwisz się o jej stan zdrowia, ale obiecałeś/aś, że nie będziesz z nikim rozmawiał/a o tym, że ona jest użależniona.

Jak mógłbyś/abyś odpowiedzieć na pytanie pedagoga szkolnego, jeżeli chciałbyś/abyś jednocześnie dochować danego przyjaciółce słowa i uniknąć kłamstwa?

Przedstaw swoją odpowiedź (maksymalnie 40 słów), uwzględniając następujące punkty (1-4):

1. Nawiąż do pytania pedagoga szkolnego.

2. Dotrzymaj danej obietnicy.

3. Wyraź swoje zaniepokojenie stanem zdrowia koleżanki.

4. Poinformuj koleżankę, że pedagog szkolny postawił Ci takie pytanie i jak na nie odpowiedziałeś/aś.

Mógłbym/abym powiedzieć pedagogowi szkolnemu, że:

Źródło: TKM-EP.

W instrukcji przygotowanej dla ewaluatora podano explicite kryteria, według których ta wypowiedź ma być oceniona. Im więcej spełnionych kryteriów, tym wyższa liczba punktów. Odpowiadający nie osiągnie jednak najwyższego wyniku przez to, że sformułuje wypowiedź według podanych punktów, lecz gdy w swojej wypowiedzi zademonstruje logicznie spójne powiązanie szczegółowych aspektów problemu.

W powyższym przykładzie odwołano się do sytuacji problemowej, z którą wypełniający test młodzi ludzie mogą dość łatwo się utożsamić. Badaczom nie chodzi jednak o to, czy respondenci potrafią wczuć się w opisany problem ani czy w swoim własnym życiu mieli do czynienia z podobnym konfliktem interesów, lecz o to, jakie strategie myślenia zastosują, żeby rozwiązać dylemat. W trakcie 
konceputalizacji TKM-EP istotną rolę odgrywało odróżnienie pytań testowych od pytań dydaktycznych. Te ostatnie są sposobem sprawdzania wiadomości i umiejętności, w którym chodzi przede wszystkim o upewnienie się przez nauczyciela, że uczniowie odpowiednio, tj. zgodnie z przyjętymi celami, przyswoili sobie treści zaprezentowane podczas lekcji. W związku ze stricte reprodukcyjnym charakterem $\mathrm{w}$ pytaniu dydaktycznym $\mathrm{z}$ zasady nie uwzględnia się opisanego $\mathrm{w}$ poprzednim podrozdziale procesu uczenia się z negatywnych doświadczeń. Inaczej jest natomiast w pytaniach testowych, w których nie „odpytuje się" po prostu uczniów z ich wiedzy i umiejętności, lecz przedstawia się im do rozważenia pewien problem. Pytania testowe mają za zadanie ujęcie skrystalizowanej już cząstkowej kompetencji moralno-etycznej, a nie wywołanie w uczącym się (kolejnego) doświadczenia nieciagłości, po to, żeby przystąpić do zrealizacji procesu dydaktycznego. Od strony psychometrycznej ich funkcją jest identyfikacja i pomiar poziomu cząstkowej kompetencji moralno-etycznej.

W przedstawionym powyżej rozróżnieniu między pytaniami dydaktycznymi i zastosowanymi w TKM-EP pytaniami testowymi ukrywa się główny zamiar jakościowej części badania ETiK-International Edynburg. Zamiar ten polega na rozszerzeniu wiedzy uzyskanej na temat uczenia się z negatywnych doświadczeń, której niewątpliwie dostarcza rozwiązywanie pytań testowych w TKM-EP, należy ją rozszerzyć zwłaszcza w odniesieniu do nieciągłości, jakie ujawniają się w przejściach między poszczególnymi poziomami oczekiwań.

Wciąż prowizoryczne pytania do studium jakościowego brzmią następująco:

1) jaką rolę u uczniów odrywają doświadczenia nieciągłości w uczeniu się w związku z osiągnięciem czwartego poziomu w zakresie KPDM-E?

2) czy i w jaki sposób respondenci przy rozwiązywaniu pytań testowych i związanych z nimi dylematów biorą pod uwagę nauczanie szkolne, a w szczególności uczenie się z negatywnych doświadczeń i nieciągłości?

3) czy i w jaki sposób respondenci przy rozwiązywaniu pytań testowych i związanych z nimi dylematów odnoszą się do osobistego kontekstu biograficznego i uwzględniają własne doświadczenia?

4) jaką rolę w przepracowywaniu sytuacji problemowych, ktore przedstawiono w pytaniach testowych, odgrywa zdolność robienia fikcyjnych doświadczeń (imaginative Erfahrungen) i jak te doświadczenia oddziałują na odpowiedzi w TKM-EP?

\section{Przewidywane znaczenie studium jakościowego na kształcenie i dokształcenie nauczycieli}

Jak zreferowano powyżej, według szkockiego Curriculum for Excellence (CfE), zakres treściowy opisywany za pomocą skrótu RME (Religious and Moral Education) ma ogrywać centralną rolę w rozwoju zdolności myślenia refleksyjnego i krytycznego. Nauczania RME nie ogranicza się do przyswojenia odpowiednich treści z zakresu filozofii i etyki, lecz CfE wprost obliguje nauczycieli do wywołania 
w uczniach moral challenges. Jednym z możliwych sposobów zrealizowania tego wymogu programowego jest przepracowywanie podczas zajęć hipotetycznych dylematów moralnych, które w ramach nauczania szkolnego mogą pełnić funkcję inspirującą do reflektowania swoich własnych przekonań moralno-etycznych. W dotychczasowych badania prowadzonych w tym zakresie dowiedziono, że w „sztucznych” warunkach szkolnych wywołanie moral challenges jest trudne $\mathrm{z}$ wielu powodów. Jednym $\mathrm{z}$ nich jest ten, że uczniowie mogą czuć się przytłoczeni trudnością problemu i dlatego nie podejmują w ogóle postawionego przed nimi wyzwania (Oser, Spychiger 2005).

Po to, żeby można było na lekcjach pracować w oparciu o negatywne doświadczenia, konieczne jest pogłębienie u nauczycieli rozumienia, czym te doświadczenia są i w jaki sposób mogą być generowane w warunkach szkolnych. Spełnienie tego warunku sprawi, że być może będzie można stosować negatywne doświadczenia uczniów jako swoistego rodzaju metodę nauczania (Bryce 2013). W tym kontekście wyniki badania ETiK-International z Edynburga - ilościowe i jakościowe - mogą przyczynić się do rozwoju potencjału nauczania szkolnego, w tym przypadku w zakresie kształcenia moralno-etycznego. Zapoznanie kandydatów na nauczycieli w ramach studiów uniwersyteckich i pracujących już nauczycieli za pośrednictwem kursów podyplomowych z koncepcją kompetencji moralno-etycznych i sposobami rozwijania kompetencji cząstkowych wydaje się działaniem zgodnym ze wskazanym powyżej celem podnoszenia jakości pracy w szkole.

\section{Przetłumaczył z języka niemieckiego Dariusz Stępkowski}

\section{Bibliografia}

Benner D. (2003). Kritik und Negativität. Ein Versuch zur Pluralisierung von Kritik in Erziehung, Pädagogik und Erziehungswissenschaft. W: Kritik in der Pädagogik. 46. Zeszyt tematyczny czasopisma „Zeitschrift für Pädagogik”, s. 96-110.

Benner D. (2008). Moralność a kształcenie. O ich problematycznym stosunku w greckiej paidei i w nowożytnej teorii kształcenia, tłum. D. Stępkowski. „Kwartalnik Pedagogiczny", nr 3, s. 69-100. Ten sam tekst ukazał się w języku polskim pod zmienionym tytułem: Przekaz moralności przez doświadczenie negatywne i etyka eksperymentalna jako adekwatne formy współczesnego wychowania moralnego. W. D. Benner (2008). Edukacja jako kształcenie i kształtowanie. Moralność - kultura - demokracja - religia. Warszawa: Wydawnictwo Uniwersytetu Kardynała Stefana Wyszyńskiego, s. 29-6o.

Benner D., English R.A. (2004). Critique and Negativity: Toward the Pluralisation of Critique in Educational Practice, Theory and Research. „Journal of Philosophy of Education", nr 38, z. 3, s. 409-428.

Benner D., Nikolova R. (red.) (2016). Ethisch-moralische Kompetenzals Teilöffentlicher Bildung. Der Berliner Ansatz zur Konstruktion und Erhebung ethisch-moralischer 
Kompetenzniveaus im öffentlichen Erziehungs- und Bildungssystem mit einem Ausblick auf Projekte zu ETiK-International. Paderborn-München-WienZürich: Schöningh.

Brüggen F. (1988). Lernen - Erfahrung - Bildung oder über Kontinuität und Diskontinuität im Lernprozess. „Zeitschrift für Pädagogik”, nr 34, s. 299-313.

Bryce T. (2013). Assessment in Scottish Schools. W: T.G. Bryce, W.M. Humes, D. Gillies, A. Kennedy (red.). Scottish Education. Fourth Edition: Referendum. Edinburgh: Edinburgh University Press, s. 665-68o.

Burbules N.C. (200o). Aporias, Webs, and Passages: Doubt as an Opportunity to Learn. „Curriculum Inquiry”, nr 30, s. 171-187.

Chater M., Erricker C. (2013). Does Religious Education Have a Future? London: Routledge.

Conroy J.C., Lundie D., Davis R.A., Baumfield V., Barnes L.P., Gallagher T., Lowden K., Bourque N., Wenell K. (2013). Does Religious Education Work? A multidimensional Investigation. London: Bloomsbury.

Department for Education (2014). National Curriculum. Manchester: DfE. Dostępny na: https://www.gov.uk/government/publications/national-curriculum-in-england-framework-for-key-stages-1-to-4/the-national-curriculum-in-england-framework-for-key-stages-1-to-4 (otwarto 21.03.2016).

Dewey J (1963). Demokracja i wychowanie. Wstęp do filozofi wychowania. Warszawa: „Książka i Wiedza”.

Dewey J. (2014). Doświadczenie i edukacja. Warszawa: Warszawska Fima Wydawnicza.

Eaude T. (2012). Spiritual and Moral Development. W: L.P. Barnes (red.). Debates in Religious Education. Abingdon: Routledge, s. 120-131.

Education Scotland (2014a). Curriculum Impact Review: Religious and Moral Education 3-18. Livingston: Education Scotland.

Education Scotland (2014b). Religious and Moral Education: Assessing Progress and Achievement. Livingston: Education Scotland.

Education Scotland-HWL (brak daty). Curriculum for Excellence: Health and Wellbeing across Learning: Responsibilities for All-Principles and Practice. Livingston: Education Scotland. Dostępny na: https://www.educationscotland. gov.uk/Images/hwb_across_learning_principles_practice_tcm4-540402.pdf (otwarto 13.03.2016).

Education Scotland-PoC (brak daty). The Purpose of the Curriculum. Livingston: Education Scotland. Dostępny na: http://www.educationscotland.gov.uk/learningandteaching/the curriculum/whatiscurriculumforexcellence/thepurposeofthecurriculum/index.asp (otwarto 13.3.2016).

Education Scotland-RMEEO (brak daty). Curriculum for Excellence: Religious and Moral Education-Experiences and Outcomes. Livingston: Education Scotland. Dostępny na: https://www.educationscotland.gov.uk/Images/rme_experiences_outcomes_tcm4-539887.pdf (otwarto 13.3.2016). 
Education Scotland-RMEPP (brak daty). Curriculum for Excellence-Religious and Moral Education: Principles and Practice. Livingston: Education Scotland. Dostępny na: https://www.educationscotland.gov.uk/Images/rme_principles_ practice_tcm4-540203.pdf (otwarto 13.03.2016).

English A.R. (2006). Eksperymentalna struktura ludzkiego uczenia się. Analiza porównawcza roli negatywnego doświadczenia w teorii Herbarta i Dewey’a, tłum. D. Stępkowski. W: J. Piskurewicz, D. Stępkowski (red.). Herbart znany i nieznany. $W$ dwusetna rocznice wydania 'Pedagogiki ogólnej'. Warszawa: Wydawnictwo Salezjańskie, s. 118-136.

English A.R. (2013). Discontinuity in Learning. Dewey, Herbart and Education as Transformation. New York: Cambridge University Press.

English, A. R. (2016). John Dewey and the Teacher in A Globalized World: Imagination, Empathy and 'Third Voice'. „Journal of Educational Philosophy and Theory", nr 10 (w druku).

Fesmire S. (2003). John Dewey and Moral Imagination. Pragmatism in Ethics. Bloomington: Indiana University Press.

Hartshorn B. (2008). Religious and Moral Education. W: T.G.K. Bryce, W.M. Humes (red.). Scottish Education. Beyond Devolution. Edinburgh: Edinburgh University Press, s. 375-380.

Hedge N., MacKenzie A. (2016). Scotland's curriculum for Excellence: a defence of autonomy and personhood. „Oxford Review of Education”, nr 42/1, s. 1-15. Dostępny na: http://dx.doi.org/10.108o/03054985.2015.112889o (otwarto 16.03.2016).

Herbart J.F. (2007). Pedagogika ogólna wywiedziona z celu wychowania, tłum. T. Stera. Warszawa: Wydawnictwo Akademickie „Żak”.

Kerdeman D. (2003). Pulled Up Short: Challenging Self-Understanding as a Focus for Teaching and Learning. "Journal of Philosophy of Education”, s. 293-308.

Lennon F. (2008). Organisation and Management in the Secondary School. W: T.G.K. Bryce, W.M. Humes (red.). Scottish Education. Beyond Devolution. Edinburgh: Edinburgh University Press, s. 383-391.

Lipman M. (2003). Thinking in Education. New York: Cambridge University Press. McKinney S. (2012). Religious education in the United Kingdom and Ireland Scotland. W: L.P. Barnes (red.). Debates in Religious Education. Abingdon: Routledge, s. 39-44.

Meyer-Drawe K. (2008). Diskurse des Lernens. München: Wilhelm Fink.

Miller J., McKenna U. (2012). Religion and religious education: comparing and contrasting pupils' and teachers' views in an English school. W: R. Jackson (red.). Religion, Education, Dialogue and conflict: Perspectives on Religious Education Research. Abingdon: Routledge.

Nixon G. (2008). Religious and Moral Education (RME). W: T.G.K. Bryce, W.M. Humes (red.). Scottish Education. Beyond Devolution. Edinburgh: Edinburgh University Press, s. 560-577. 
Nixon G. (2013a). Curriculum: Early Years and Primary - Religious and Moral Education. W: T.G.K. Bryce, W.M. Humes (red.). Scottish Education. Beyond Devolution. Edinburgh: Edinburgh University Press, s. 492-500.

Nixon, G. (2013b). Curriculum Secondary - Religious and Moral Education. W: T.G.K. Bryce, W.M. Humes (red.). Scottish Education. Beyond Devolution. Edinburgh: Edinburgh University Press, s. 640-645.

OECD (2015). Improving Schools in Scotland. An OECD Perspective. Paris: Organization for Economic Cooperation and Development (OECD).

Ofsted (2015). School Inspection Handbook. Dostępny na: https://www.gov.uk/go vernment/uploads/system/uploads/attachment_data/file/458866/School_inspection_handbook_section_5_from_September_2015.pdf (otwarto 21.03.2016).

Oser F. (1998). Negative Moralität und Entwicklung. Ein undurchsichtiges Verhältnis. „Ethik und Sozialwissenschaften”, nr 9, z. 4, s. 597-608.

Oser F. (2005). Negatives Wissen und Moral. W: Erziehung - Bildung - Negativität, 49. numer specjalny czasopisma „Zeitschrift für Pädagogik”, s. 171-181.

Oser F., Spychiger M. (2005). Lernen ist schmerzhaft: Zur Theorie des negativen Wissens und zur Praxis der Fehlerkultur. Weinheim: Beltz.

Paul R. (2012). Critical Thinking: What every person needs to survive in a rapidly changing world. Tomales: Foundations for Critical Thinking.

Peterson A., Lexmond J., Hallgarten J., Kerr D. (2014). Schools with Soul: A new approach to Spiritual, Moral, Social and Cultural Education. Report of the Royal Society of Arts (RSA). Action Research Center. Dostępny na: https://www.thersa. org/discover/publications-and-articles/reports/schools-with-soul-a-new-approach-to-spiritual-moral-social-and-cultural-education (otwarto 21.03.2016).

Platon (1990). Państwo, tłum. W. Witwicki. Warszawa: Wydawnictwo AKME.

Priestly M. (2013). The 3-18 Curriculum in Scottish Education. W: T.G. Bryce, W.M. Humes, D. Gillies, A. Kennedy (red.). Scottish Education. Fourth Edition: Referendum. Edinburgh: Edinburgh University Press.

Scottish Education Department (SED) (1972). Moral and Religious education in Scottish Schools (the Millar Report). Edinburgh: HMSO.

Scottish Executive (2006). A Curriculum for Excellence: Building the Curriculum 1: The contribution of Curriculum Areas. Edinburgh: SE.

Watson B. (2012). Why religious education matters. W: L. P. Barnes (red.). Debates in Religious Education. Abingdon: Routledge, s. 13-21. 


\title{
DISCONTINUITY AS A LENS FOR ANALYSING STUDENTS' THINKING AROUND MORAL DILEMMAS - A QUALITATIVE STUDY OF ETIK-INTERNATIONAL-EDINBURGH
}

\begin{abstract}
The Project ETiK, which began at Humboldt University Berlin, created a test to differentiate students' moral competency into three sub-areas of competency, 'basic knowledge', 'judgment' and 'ability to create plans for action' and also determines different levels of competency a person can have within these three subareas. ETiK-Edinburg plans to extend the ETiK-International competency test in two ways. It will use the current Scottish curriculum, Curriculum for Excellence, to test ETiK's hypothesis and will add a qualitative study focused on understanding the role played by experiences of discontinuity in students' thinking as they move from one level of competency to the next higher level. Discontinuity refers to the moments in experience when we are challenged by a new idea, perspective, or object that we do not immediately know how to respond to.

In this chapter, I first provide some background on the role of ethical-moral education in the UK more broadly, and identify the unique role of ethical-moral education in Scotland. In the second section, I show the alignment between the specified criteria for the highest levels of 'achievement' in the subject area of 'Religious and Moral Education' in Scotland's Curriculum for Excellence, and the criteria for the highest levels of 'competency' in ETiK's moral competency levels. In the final section, I discuss my design for a qualitative study, which will serve to help further our understanding of the role played by discontinuity in students' thinking when they are responding to moral dilemmas. In the conclusion, I highlight how the results of the quantitative and qualitative studies will inform the design of a professional development course for primary and secondary 'Religious and Moral Education' teachers.
\end{abstract}

Keywords: ethical-moral education, moral competency, discontinuity, ETiK-International.

Andrea R. English - doktor pedagogiki, profesor w Moray House School of Education $\mathrm{w}$ University of Edinburgh (Wielka Brytania). Zainteresowania badawcze: teoria wychowania, teoria kształcenia, wychowanie moralne. Autorskie publikacje książkowe: Discontinuity in Learning: Dewey, Herbart and Education as Transformation (New York 2013). Adres mejlowy: andrea.english@ed.ac.uk. 